\title{
PERTUMBUHAN DAN HASIL TANAMAN INDIGOFERA (Indigofera zollingeriana) DAN KELOR (Moringa oleifera Lam) PADA DOSIS PUPUK BIOURIN BERBEDA
}

\author{
Huge Fajri Al - Fath, Ni Made Witariadi, dan Ni Nyoman Candraasih Kusumawati \\ Fakultas Peternakan Universitas Udayana, Denpasar-Bali \\ e-mail: hugefajri25@gmail.com
}

\begin{abstract}
ABSTRAK
Penelitian bertujuan untuk mendapat informasi tentang pertumbuhan dan hasil tanaman indigofera (Indigofera zollingeriana) dan kelor (Moringa oleifera Lam) pada dosis pupuk biourin berbeda. Penelitian dilaksanakan di Rumah Kaca, Stasiun Penelitian Sesetan, Fakultas Peternakan, Universitas Udayana selama 12 minggu. Rancangan yang digunakan adalah rancangan acak lengkap (RAL) pola split plot. Main plot/petak utama yaitu jenis tanaman terdiri dari tanaman indigofera (Indigofera zollingeriana) dan kelor (Moringa oleifera Lam). Subplot/anak petak yaitu dosis pupuk biourin terdiri dari: o $1 \mathrm{ha}^{-1}$ (Do), 2.5001 $\mathrm{ha}^{-1}$ (D1), 5.000 $1 \mathrm{ha}^{-1}$ (D2), 7.500 $1 \mathrm{ha}^{-1}$ (D3) dan $10.0001 \mathrm{ha}^{-1}$ (D4). Terdapat 10 kombinasi perlakuan dan diulang sebanyak 3 kali sehingga terdapat 30 unit percobaan. Variabel yang diamati adalah tinggi tanaman, jumlah daun, jumlah bintil akar, jumlah cabang, berat kering daun, berat kering batang, berat kering akar, berat kering total hijauan, nisbah berat kering daun dengan berat kering batang, nisbah berat kering total hijauan dengan berat kering akar (top root ratio) dan luas daun per pot. Hasil penelitian menunjukkan bahwa terjadi interaksi antara jenis tanaman dengan dosis pupuk biourin terhadap variabel tinggi tanaman, jumlah cabang, dan berat kering batang. Jenis tanaman indigofera (Indigofera zollingeriana) memberikan pertumbuhan dan hasil yang lebih baik dibandingkan dengan kelor (Moringa oleifera Lam). Pemberian pupuk biourin dapat meningkatkan pertumbuhan dan hasil pada kedua jenis tanaman. Pemupukan biourin dengan dosis $10.0001 \mathrm{ha}^{-1}$ menghasilkan pertumbuhan dan hasil lebih tinggi. Berdasarkan hasil penelitian dapat disimpulkan bahwa terjadi interaksi antara jenis tanaman dengan dosis pupuk biourin terhadap variabel tinggi tanaman, jumlah cabang, dan berat kering batang dan dosis $10.000 \mathrm{l} \mathrm{ha}^{-1}$ menunjukkan pertumbuhan dan hasil yang terbaik.
\end{abstract}

Kata kunci: biourin, hasil, Indigofera zollingeriana, Moringa oleifera Lam, pertumbuhan

\section{GROWTH AND YIELD OF Indigofera zollingeriana AND Moringa oleifera Lam ON DIFFERENT BIOURINE FERTILIZER DOSAGES}

\begin{abstract}
The research aimed to obtain information about the growth and yield of Indigofera zollingeriana and Moringa oleifera Lam on different biourine fertilizer dosages. The study was conducted at the Greenhouse, Sesetan Research Station, Faculty of Animal Husbandry, Udayana University for 12 weeks. The design used was a completely randomized design (CRD) with split plot pattern. The main plot was types of leguminocea consisted of Indigofera zollingeriana and Moringa oleifera Lam. The sub plot was biourine fertilization dosage consisting of: o l ha-1 (Do), $2.500 \mathrm{l} \mathrm{ha}^{-1}$ (D1), 5.000 l ha-1 (D2), 7.500 l ha-1 (D3) and $10.000 \mathrm{l} \mathrm{ha}^{-1}$ (D4). There were 10 treatment combinations and repeated 3 times so there were 30 experimental units. The variables observed were plant height, number of leaves, number of nodules, number of branches, leaf dry weight, stem dry weight, root dry weight, total forage dry weight, leaf dry weight with stem dry weight ratio, total forage dry weight with root dry weight (top root ratio) and leaf area per pot. The results of this research showed that there was an interaction between the types of legumes and biourine fertilizer dosages on the variable plant height, number of branches, and stem dry weight. Indigofera zollingeriana showed better growth and yield than Moringa oleifera Lam. Application of biourine fertilization could increase growth and yield in both types of legumes. Biourine fertilization with a dosage $10.0001 \mathrm{ha}^{-1}$ had higher growth and yield. Based on the results of this research concluded that there was an interaction between the types of legumes with biourine dosages on variable plant height, number of branches and stem dry weight, and dosage $10.000 \mathrm{l} \mathrm{ha}^{-1}$ showed the best growth and yield.
\end{abstract}

Key words: biourine, growth, Indigofera zollingeriana, Moringa oleifera Lam, yield 


\section{PENDAHULUAN}

Hijauan merupakan pakan utama untuk ternak ruminansia yang memiliki kandungan nutrien seperti energi, protein, lemak, serat, vitamin dan mineral. Hijauan pakan sebagai sumber serat kasar yang berasal dari tumbuh-tumbuhan, terutama daun-daunan atau bahkan ranting serta bunga. Hijauan pakan bagi ternak ruminansia berasal dari bangsa rumput (Gramineae), kacang-kacangan (Leguminoseae), dan tanaman lainnya. Kebutuhan hijauan pakan semakin meningkat seiring dengan bertambahnya populasi ternak, sehingga produktivitas hijauan pakan perlu ditingkatkan. Usaha untuk meningkatkan produksi dan mendapatkan hijauan pakan yang berkualitas bagi ternak yaitu dengan cara mengembangkan jenis tanaman leguminosa.

Tanaman leguminosa memiliki nilai nutrisi yang lebih baik daripada rumput. Selain memiliki kualitas nutrisi yang lebih tinggi juga mampu menyediakan bahan pakan yang stabil dalam jangka yang lebih panjang terutama selama musim kemarau karena tanaman legum memiliki daya jelajah akar yang lebih jauh sehingga mampu mendapat lebih banyak unsur hara dibanding tanaman rumput. Hijauan leguminosa dikenal mengandung protein, vitamin dan mineral yang lebih tinggi dibandingkan hijauan jenis rumput, sehingga memiliki potensi sebagai sumber protein yang murah dan dapat diproduksi secara lokal. Salah satu jenis leguminosa yang potensial dalam menunjang kebutuhan penyediaan hijauan pakan yaitu tanaman indigofera (Indigofera zollingeriana). Indigofera merupakan salah satu tanaman pakan yang memiliki kandungan nutrisi dan produksi yang tinggi serta sangat toleran terhadap kondisi tanah kering, genangan, tanah berkadar garam tinggi (saline) dan tanah masam (Hassen et al., 2007). Sebagai pakan hijauan, Indigofera zollingeriana mempunyai kualitas nutrisi tinggi dengan kandungan protein yang bervariasi yaitu 21-25\% (Tarigan et al., 2010). Jenis leguminosa lain yang tersedia di setiap musim dan sebagai sumber pakan yaitu tanaman kelor (Moringa oleifera Lam). Kelor merupakan jenis legum yang kandungan nutrisinya bernilai tinggi sebagai hijauan pakan. Kelor dapat tumbuh pada daerah tropis dan subtropis pada semua jenis tanah dan tahan terhadap musim kemarau dengan toleransi terhadap kekeringan sampai 6 bulan (Mendieta-Araica et al., 2013). Pengembangan tanaman kelor dapat dilakukan secara generatif (biji) maupun vegetatif (stek batang).

Upaya peningkatan produksi hijauan dapat dicapai dengan melakukan pemeliharaan yang baik. Salah satu cara pemeliharaan tanaman yang penting adalah pemupukan. Pemupukan dapat menggunakan pupuk organik maupun pupuk anorganik pada waktu pengolahan tanah, yang bertujuan untuk meningkatkan kesuburan tanah agar mencapai produksi yang maksimal. Kendala penggunaan pupuk anorganik yang berlebihan menyebabkan beberapa masalah pada tanah dan dapat mencemari air, sehingga keseimbangan alam menjadi terganggu (Indriani, 2011). Upaya peningkatan penggunaan pupuk yang dikaitkan dengan aspek pendukung kelestarian alam yaitu dengan penggunaan pupuk organik (Kanisius, 1983).

Pemanfaatan pupuk organik cair yang berasal dari urin sapi (biourin) menjadi salah satu alternatif untuk memecahkan masalah tersebut. Biourin mampu meningkatkan ketersediaan, kecukupan dan efisiensi serapan hara bagi tanaman yang mengandung mikroorganisme sehingga dapat meningkatkan hasil tanaman secara maksimal. Hasil penelitian dari Aisyah et al. (2011) menunjukkan bahwa pupuk urin sapi mengandung hormon tertentu yang dapat merangsang perkembangan tanaman dan mengandung lebih banyak N dan K. Manfaat lain dari pupuk organik cair yaitu dapat mendorong dan meningkatkan klorofil daun sehingga tanaman menjadi kokoh dan kuat; meningkatkan daya tahan tanaman terhadap kekeringan, cekaman cuaca dan serangan hama dan penyakit, serta meningkatkan pembentukan bunga dan bakal buah (Guntoro, 2006).

Penelitian Adijaya et al. (2007), pemberian urin sapi dengan dosis $7.5001 \mathrm{ha}^{-1}$ mampu meningkatkan biomassa rumput raja sebesar 90,18\% dibanding tanpa pemupukan. Hasil penelitian Kusumawati et al. (2017) menunjukkan bahwa pemberian pupuk biourin sapi dengan dosis $7.5001 \mathrm{ha}^{-1}$ (D2) pada jarak tanaman $10 \mathrm{~cm} 20 \mathrm{~cm}(\mathrm{~J} 1)$ menghasilkan pertumbuhan dan hasil hijauan rumput Panicum maximum yang paling baik dibanding dengan perlakuan yang lain. Pemupukan kombinasi pupuk urea dosis $75 \mathrm{~kg} \mathrm{ha}^{-1}$ dan pupuk biourin dosis $7.500 \mathrm{l} \mathrm{ha}^{-1}$ memberikan hasil terbaik terhadap produktivitas rumput Panicum maximum cv. Trichoglume (Witariadi dan Kusumawati, 2020). Nuriyasa et al. (2012) menyatakan bahwa semakin tinggi dosis pemberian pupuk biourin maka semakin tinggi pula tingkat produktivitas tanaman yang dipupuk.

Berdasarkan permasalahan di atas, maka perlu dilakukan penelitian mengenai pertumbuhan dan hasil tanaman indigofera (Indigofera zollingeriana) dan kelor (Moringa oleifera Lam) yang diberi perlakuan pupuk biourin dengan dosis berbeda.

\section{MATERI DAN METODE}

Percobaan dilakukan di Rumah Kaca Stasiun Penelitian Sesetan Fakultas Peternakan Universitas Udayana. Bibit tanaman yang digunakan adalah tanaman indigofera (Indigofera zollingeriana) dan 
Tabel 1. Pertumbuhan Tanaman Indigofera (Indigofera zollingeriana) dan Kelor (Moringa oleifera Lam) pada Dosis Pupuk Biourin Berbeda

\begin{tabular}{|c|c|c|c|c|c|c|c|c|}
\hline \multirow{2}{*}{ Variabel } & \multirow{2}{*}{$\begin{array}{l}\text { Jenis tana- } \\
\text { man }^{1)}\end{array}$} & \multicolumn{5}{|c|}{ Dosis pupuk $\left.{ }^{2}\right)$} & \multirow{2}{*}{ Rataan } & \multirow{2}{*}{ SEM $^{3)}$} \\
\hline & & Do & D1 & D2 & D3 & D4 & & \\
\hline \multirow{3}{*}{$\begin{array}{l}\text { Tinggi tanaman } \\
(\mathrm{cm})\end{array}$} & $\mathrm{TI}$ & $55,33^{\text {cd }}$ & $63,67^{\mathrm{bcd}}$ & $55,33^{\text {cd }}$ & $64,33^{\text {bcd }}$ & $66,67^{\text {bcd }}$ & $\left.61,07^{\mathrm{X}} 4\right)$ & 5,52 \\
\hline & TK & $71,67^{\mathrm{bc}}$ & $51, \mathrm{OO}^{\mathrm{de}}$ & $79,00^{\mathrm{ab}}$ & $37,00^{\mathrm{e}}$ & $89,5^{0^{a}}$ & $65,63^{\mathrm{X}}$ & \\
\hline & Rataan & $63,50^{\mathrm{B}}$ & $57,33^{\mathrm{BC}}$ & $67,17^{\mathrm{AB}}$ & $50,67^{\mathrm{C}}$ & $78,08^{A}$ & & \\
\hline \multirow{3}{*}{$\begin{array}{l}\text { Jumlah daun } \\
\text { (helai) }\end{array}$} & $\mathrm{TI}$ & 16,00 & 14,33 & 14,67 & 15,67 & 16,33 & $15,40^{\mathrm{X}}$ & 2,36 \\
\hline & TK & 8,00 & 11,00 & 11,67 & 10,33 & 12,00 & $10,60^{Y}$ & \\
\hline & Rataan & $12,00^{\mathrm{A}}$ & $12,67^{\mathrm{A}}$ & $13,17^{\mathrm{A}}$ & $13, \mathrm{OO}^{\mathrm{A}}$ & $14,17^{\mathrm{A}}$ & & \\
\hline \multirow{3}{*}{$\begin{array}{l}\text { Jumlah bintil } \\
\text { akar (buah) }\end{array}$} & TI & 76.00 & 70,00 & 40,33 & 114,33 & 75,00 & $75,13^{\mathrm{X}}$ & 17,11 \\
\hline & TK & 0,00 & 0,00 & 0,00 & 0,00 & 0,00 & $0,00^{Y}$ & \\
\hline & Rataan & $38, \mathrm{oo}^{\mathrm{A}}$ & $35, \mathrm{OO}^{\mathrm{A}}$ & $20,17^{\mathrm{A}}$ & $57,17^{\mathrm{A}}$ & $37,5 \mathrm{O}^{\mathrm{A}}$ & & \\
\hline \multirow{3}{*}{$\begin{array}{l}\text { Jumlah cabang } \\
\text { (batang) }\end{array}$} & $\mathrm{TI}$ & $0.00^{b}$ & $0,00^{b}$ & $\mathrm{o}, 33^{\mathrm{b}}$ & $0,33^{b}$ & $0,00^{b}$ & $0,13^{\mathrm{Y}}$ & 0,39 \\
\hline & TK & $0,00^{b}$ & $0,67^{\mathrm{b}}$ & $0,33^{b}$ & $3,33^{\mathrm{a}}$ & $0,00^{b}$ & $0,87^{\mathrm{X}}$ & \\
\hline & Rataan & $0,00^{\mathrm{B}}$ & $0,33^{\mathrm{B}}$ & $0,33^{\mathrm{B}}$ & $1,83^{\mathrm{A}}$ & $0,00^{B}$ & & \\
\hline
\end{tabular}

Keterangan:

1) TI = Tanaman Indigofera (Indigofera zollingeriana), TK = Tanaman Kelor (Moringa oleifera Lam)

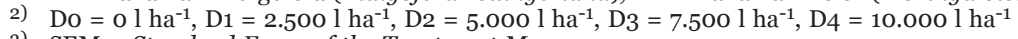

3) SEM = Standard Error of the Treatment Means $(\mathrm{P}>0,05)$, sedangkan nilai dengan huruf yang berbeda pada baris dan kolom yang sama menunjukkan berbeda nyata $(\mathrm{P}<0,05)$.

kelor (Moringa oleifera Lam). Tanah yang digunakan berasal dari tanah yang ada di sekitar farm kampus Bukit Jimbaran Fakultas Peternakan Universitas Udayana, yang memiliki tekstur lempung berliat dengan kandungan $\mathrm{C}$ organik 1,29\% (rendah), $\mathrm{N}$ total 0,12\% (rendah), P tersedia 15,61 ppm (sedang), kadar air kering udara (KU) 9,91\% dan kapasitas lapang 30,13\%.

Tanah yang akan dipakai terlebih dahulu dikering udarakan, kemudian ditumbuk halus, selanjutnya diayak dengan tujuan agar ukuran partikel tanah merata. Tanah ditimbang dan dimasukkan ke dalam pot yang masing-masing diisi sebanyak $4 \mathrm{~kg}$ tanah kering udara. Tanah dalam pot kemudian disiram dengan air sampai kapasitas lapang.

Percobaan menggunakan pot berbahan dasar plastik yang berdiameter $26 \mathrm{~cm}$ dan tinggi $19 \mathrm{~cm}$ sebanyak 30 buah. Pupuk yang digunakan dalam penelitian adalah pupuk biourin sapi yang diperoleh dari kelompok Simantri di Desa Kelating, Kecamatan Kerambitan, Kabupaten Tabanan, Bali. Analisa kandungan unsur hara dilakukan di Laboratorium Biosain Politeknik Negeri Jember.

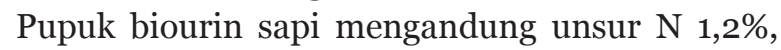
P205 0,58\%, K 0,73\%, dan C-organik 2,67\%. Rancangan percobaan yang digunakan adalah rancangan acak lengkap (RAL) pola split plot. Faktor pertama yaitu jenis tanaman yang terdiri dari tanaman indigofera (TI) dan tanaman kelor (TK) dan faktor kedua dosis pupuk biourin terdiri dari o $1 \mathrm{ha}^{-1}$ (Do), 2.500 $1 \mathrm{ha}^{-1}$ (D1), 5.000 $1 \mathrm{ha}^{-1}$ (D2), 7.500 $1 \mathrm{ha}^{-1}$ (D3) and $10.000 \mathrm{l} \mathrm{ha}^{-1}$ (D4). Terdapat 10 kombinasi perlakuan dan diulang sebanyak 3 kali sehingga terdapat 30 unit percobaan. Peubah yang diamati meliputi: tinggi tanaman, jumlah daun, jumlah bintil akar, jumlah cabang, berat kering daun, berat kering batang, berat kering akar, berat kering total hijauan, nisbah berat kering daun dengan berat kering batang, nisbah berat kering total hijauan dengan berat kering akar dan luas daun per pot.

\section{HASIL DAN PEMBAHASAN}

Hasil penelitian menunjukkan bahwa terjadi interaksi antara jenis tanaman dengan dosis pupuk biourin. Interaksi antara perlakuan jenis tanaman dan dosis pupuk biourin berpengaruh nyata terhadap variabel tinggi tanaman, jumlah cabang, dan berat kering batang (Tabel 1 dan Tabel 2). Hal ini berarti faktor jenis tanaman dan dosis pupuk biourin saling mempengaruhi dalam menentukan tinggi tanaman, jumlah cabang, dan berat kering batang. Sesuai dengan pendapat Gomez dan Gomez (1995) yang menyatakan bahwa dua faktor perlakuan dikatakan berinteraksi apabila pengaruh satu faktor perlakuan berubah pada saat perubahan taraf faktor perlakuan lainnya. Pada variabel lainnya tidak terjadi interaksi antara jenis tanaman dengan dosis pupuk biourin $(\mathrm{P}>0,05)$. Hal ini karena jenis tanaman dan dosis pupuk biourin bekerja sendiri-sendiri. Sesuai dengan pernyataan Steel dan Torrie (1991) yang menyatakan bahwa bila pengaruh interaksi berbeda tidak nyata, maka disimpulkan bahwa diantara faktor-faktor perlakuan tersebut berdiri sendiri.

Hasil penelitian menunjukkan bahwa tanaman kelor tidak nyata $(\mathrm{P}>0,05)$ tumbuh lebih tinggi dan jumlah cabangnya nyata $(\mathrm{P}<0,05)$ lebih banyak di- 
Tabel 2. Hasil Tanaman Indigofera (Indigofera zollingeriana) dan Kelor (Moringa oleifera Lam) pada Dosis Pupuk Biourin Berbeda

\begin{tabular}{|c|c|c|c|c|c|c|c|c|}
\hline \multirow{2}{*}{ Variabel } & \multirow{2}{*}{$\begin{array}{c}\text { Jenis } \\
\operatorname{tanaman}^{1)}\end{array}$} & \multicolumn{5}{|c|}{ Dosis pupuk ${ }^{2)}$} & \multirow{2}{*}{ Rataan } & \multirow{2}{*}{ SEM $^{3)}$} \\
\hline & & Do & D1 & D2 & D3 & D4 & & \\
\hline \multirow[t]{3}{*}{ Berat kering daun (g) } & $\mathrm{TI}$ & 6,37 & 5,27 & 5,80 & 6,30 & 5,83 & $\left.5,91^{\mathrm{X}} 4\right)$ & 0,41 \\
\hline & TK & 0,77 & 0,90 & 1,17 & 0,37 & 1,47 & $0,93^{Y}$ & \\
\hline & Rataan & $3,57^{\mathrm{A}}$ & $3,08^{\mathrm{A}}$ & $3,48^{\mathrm{A}}$ & $3,33^{\mathrm{A}}$ & $3,65^{\mathrm{A}}$ & & \\
\hline \multirow[t]{3}{*}{ Berat kering batang (g) } & $\mathrm{TI}$ & $3,57^{\mathrm{ab}}$ & $2,53^{\mathrm{ab}}$ & $3,10^{\mathrm{ab}}$ & $3,57^{\mathrm{ab}}$ & $2,83^{\mathrm{ab}}$ & $3,12^{\mathrm{X}}$ & 0,51 \\
\hline & TK & $2,50^{\mathrm{ab}}$ & $2,00^{b}$ & $3,97^{\mathrm{a}}$ & $0,5 \mathrm{O}^{\mathrm{c}}$ & $4,03^{\mathrm{a}}$ & $2,60^{X}$ & \\
\hline & Rataan & $3,03^{\mathrm{AB}}$ & $2,27^{\mathrm{B}}$ & $3,53^{\mathrm{A}}$ & $2,03^{\mathrm{B}}$ & $3,43^{\mathrm{A}}$ & & \\
\hline \multirow[t]{3}{*}{ Berat kering akar (g) } & $\mathrm{TI}$ & 2,87 & 2,43 & 1,77 & 3,90 & 2,97 & $2,79^{\mathrm{Y}}$ & 2,18 \\
\hline & $\mathrm{TK}$ & 11,17 & 9,37 & 7,93 & 2,70 & 9,67 & $8,17^{\mathrm{X}}$ & \\
\hline & Rataan & $7,02^{\mathrm{A}}$ & $5,90^{\mathrm{A}}$ & $4,85^{\mathrm{A}}$ & $3,30^{\mathrm{A}}$ & $6,32^{\mathrm{A}}$ & & \\
\hline \multirow[t]{3}{*}{ Berat kering total hijauan (g) } & $\mathrm{TI}$ & 9,93 & 7,80 & 8,90 & 9,87 & 8,67 & $9,03^{\mathrm{X}}$ & 1,50 \\
\hline & $\mathrm{TK}$ & 3,27 & 2,90 & 5,13 & 0,87 & 5,50 & $3,53^{Y}$ & \\
\hline & Rataan & $6,60^{\mathrm{A}}$ & $5,35^{\mathrm{A}}$ & $7,02^{\mathrm{A}}$ & $5,37^{\mathrm{A}}$ & $7,08^{\mathrm{A}}$ & & \\
\hline
\end{tabular}

Keterangan:

1) $\mathrm{TI}=$ Tanaman Indigofera (Indigofera zollingeriana), TK = Tanaman Kelor (Moringa oleifera Lam)

2) Do $=01$ ha-1, D1 = 2.500 l ha-1, D2 = 5.00o l ha-1, D3 = 7.500 1 ha-1, D4 = 10.0001 ha-1

3) $\mathrm{SEM}=$ Standard Error of the Treatment Means

4) Nilai dengan huruf kapital yang sama pada kolom yang sama dan huruf kecil yang sama pada baris yang sama menunjukkan berbeda tidak nyata $(\mathrm{P}>0,05)$, sedangkan nilai dengan huruf yang berbeda pada baris dan kolom yang sama menunjukkan berbeda nyata $(\mathrm{P}<0,05)$

bandingkan dengan tanaman indigofera. Sebaliknya rataan jumlah daun dan jumlah bintil akar tanaman indigofera nyata $(\mathrm{P}<0,05)$ lebih banyak daripada tanaman kelor. Hal ini mengindikasikan bahwa tanaman indigofera lebih banyak memanfaatkan unsur hara untuk pertumbuhan daun sedangkan tanaman kelor memanfaatkan unsur hara lebih banyak untuk pertumbuhan cabang. Bintil akar yang ada pada tanaman indigofera dan belum ada pada tanaman kelor mempengaruhi perkembangan vegetatif dari kedua jenis tanaman tersebut. Bintil-bintil akar yang mengandung bakteri rhizobium, menjalin interaksi simbiosis dengan tanaman inang dalam proses fiksasi nitrogen secara biologi dari udara (Mansyur, 2008). Unsur hara nitrogen merupakan salah satu unsur penting bagi tanaman yang berfungsi untuk meningkatkan pertumbuhan vegetatif tanaman terutama bagian daunnya, sehingga jumlah daun tanaman indigofera lebih banyak daripada tanaman kelor.

Hasil penelitian menunjukkan bahwa bintil akar kedua jenis tanaman terdapat perbedaan yang sangat signifikan. Pada tanaman indigofera sudah terdapat bintil-bintil akar sedangkan pada tanaman kelor tidak terdapat bintil akar. Hal ini dikarenakan ketersediaan unsur fosfor pada pupuk biourin belum cukup untuk mempengaruhi pertumbuhan bakteri rhizobium dalam pembentukan bintil akar tanaman kelor. Sesuai dengan pendapat Blair (1979) yang menyatakan unsur fosfor relatif dibutuhkan dalam jumlah banyak untuk membentuk nodul dan fiksasi nitrogen. Pada tanaman kelor penggunaan unsur hara lebih diprioritaskan untuk perkembangan akarnya tetapi tidak dengan bintil akarnya, sedangkan tanaman indigofera unsur hara diprioritaskan untuk pertumbuhan bintil akar dibanding dengan perkembangan akarnya. Selain itu, umur pemanenan (8 minggu) yang masih muda sehingga bintil akar tanaman kelor belum tumbuh. Mansyurdin (1991) menyatakan bahwa faktor genetik seperti umur tanaman dan lingkungan antara lain suhu, cahaya, kelembaban tanah, $\mathrm{pH}$ tanah, oksigen serta faktor nutrisi seperti fosfor, sulfur, kalsium, nitrogen, dan unsur-unsur mikro lainnya mempengaruhi pertumbuhan struktur dan fungsi dari bintil akar.

Hasil penelitian menunjukkan bahwa pada perlakuan pemberian pupuk biourin dengan dosis 10.000 $1 \mathrm{ha}^{-1}$ (D4) memiliki rataan tertinggi pada variabel tinggi tanaman yang secara statistik menunjukkan berbeda nyata $(\mathrm{P}<0,05)$. Hal ini mengindikasikan bahwa semakin tinggi pemberian dosis pupuk biourin pada tanaman, maka semakin tinggi pula tingkat pertumbuhan tanaman karena semakin banyak unsur hara yang tersedia bagi tanaman. Sesuai dengan pendapat yang dikemukan oleh Kerley et al. (1996) dan Widjajanto et al. (2001), bahwa semakin meningkat dosis pupuk kandang diberikan pada tanaman, maka semakin tinggi tingkat pertumbuhan dan produksi tanaman akibat meningkatnya ketersediaan unsur hara di tanah.

Berat kering daun dan berat kering total hijauan tanaman indigofera nyata $(\mathrm{P}<0,05)$ lebih tinggi tetapi berat kering batangnya tidak nyata $(\mathrm{P}>0,05)$ lebih tinggi daripada tanaman kelor. Hal ini dikarenakan jumlah daun yang ada pada tanaman indigofera lebih banyak (Tabel 1) sehingga didapatkan berat kering daun dan berat kering total hijauan yang lebih tinggi dibanding tanaman kelor. Secara morfologi tanaman indigofera memiliki ukuran daun yang lebih lebar sehingga lebih efektif dalam hal penyerapan radiasi matahari dan unsur hara. Bentuk batang yang besar dan ukuran daun yang lebar menyebabkan proses 
fotosintesis berjalan optimal, sehingga bahan kering yang dihasilkan oleh tanaman indigofera lebih tinggi daripada tanaman kelor. Sesuai dengan pendapat Budiana (1993) yang menyatakan makin tinggi laju fotosintesis maka semakin tinggi karbohidrat dan protein yang dihasilkan tanaman sehingga berat kering juga semakin tinggi. Peranan bintil akar dapat membantu mengikat nitrogen dari udara sehingga pasokan unsur hara nitrogen untuk tanaman semakin meningkat. Unsur hara nitrogen yang tersedia cukup banyak dapat meningkatkan pertumbuhan vegetatif, luas daun, dan memberikan warna lebih hijau pada tanaman sehingga proses fotosintesis berjalan lebih optimal. Dwijosepoetro (1981) menyatakan bahwa berat kering tanaman sangat dipengaruhi oleh optimalnya proses fotosintesis.

Berat kering akar pada tanaman kelor nyata $(\mathrm{P}<0,05)$ lebih tinggi dibanding dengan tanaman indigofera. Hal ini dikarenakan tanaman kelor saat masih bibit/muda memanfaatkan hara untuk diprioritaskan pada pertumbuhan akar sehingga nantinya memiliki akar yang kuat pada saat tanaman kelor sudah tumbuh tinggi. Tanaman kelor merupakan tanaman perdu yang dapat tumbuh mencapai tinggi 7-11 meter dengan batang berkayu getas (mudah patah) tetapi mempunyai akar yang kuat (Widowati, 2014).

Hasil analisis menunjukkan bahwa perlakuan pemupukan biourin dengan dosis 10.000 l/ha (D4) menghasilkan berat kering daun, berat kering batang, berat kering akar dan berat kering total hijauan cenderung tertinggi yang menunjukkan hasil berbeda tidak nyata pada semua perlakuan $(\mathrm{P}>0,05)$. Makin tinggi dosis biourin yang diberikan, maka pertumbuhan dan produksi hijauan juga akan meningkat. Hal ini karena unsur hara yang didapatkan dari pemupukan mampu meningkatkan pertumbuhan tanaman sehingga berpengaruh terhadap peningkatan produksinya. Sesuai dengan pendapat Adijaya (2010) yang menyatakan semakin tinggi dosis pupuk kandang dan biourin yang diberikan akan meningkatkan $\mathrm{N}$-total dalam tanah. Nitrogen sangat diperlukan tanaman untuk pertumbuhan vegetatif, memperbesar ukuran daun dan meningkatkan kandungan klorofil sehingga peningkatan klorofil pada daun akan mempercepat proses fotosintesis (Sutejo, 2002). Harjadi (1979) menyatakan bahwa hasil dari proses fotosintesis akan ditranslokasikan ke bagian lain dari tanaman yang akan digunakan untuk pertumbuhan vegetatif dan reproduktif.

Nisbah berat kering daun dengan berat kering batang tanaman indigofera nyata $(\mathrm{P}<0,05)$ lebih tinggi daripada tanaman kelor (1,97 vs 0,49) seperti pada Tabel 3. Hal ini dikarenakan pertumbuhan batang pada tanaman indigofera lebih rendah dibanding dengan pertumbuhan daunnya yang lebih tinggi sedangkan pada tanaman kelor sebaliknya. Ini artinya semakin tinggi jumlah daun maka kualitas tanamannya lebih baik karena kandungan karbohidrat dan protein akan lebih banyak searah dengan meningkatnya pertumbuhan daun. Sesuai dengan pendapat Tillman et al. (1991) yang menyatakan bahwa tanaman dikatakan memiliki kualitas baik apabila memberikan nilai nisbah berat kering daun dengan berat kering batang yang tinggi, karena pada umumnya daun memiliki kandungan protein lebih tinggi daripada batang. Pada perlakuan dosis pupuk biourin menunjukkan pengaruh tidak nyata $(\mathrm{P}>0,05)$ dikarenakan perbedaan nilai rataan antara satu perlakuan dengan perlakuan lain berbeda tidak nyata dengan hasil tertingginya yaitu pada dosis $7.5001 \mathrm{ha}^{-1}$ (D3) sebesar 1,40. Nisbah berat kering daun dengan berat kering batang menunjukkan perbandingan antara jumlah proporsi daun dengan proporsi batang. Banyaknya jumlah daun artinya mengandung protein dan lemak yang tinggi sehingga menghasilkan kualitas hijauan yang baik.

Nisbah berat kering total hijauan dengan berat kering akar tanaman indigofera nyata $(\mathrm{P}<0,05)$ lebih tinggi daripada tanaman kelor ( 3,52 vs 0,56$)$ dan hasil tertinggi dengan perlakuan dosis pupuk biourin yaitu pada dosis $5.0001 \mathrm{ha}^{-1}(\mathrm{D} 2)$ sebesar 3,10 berbeda nyata $(\mathrm{P}<0,05)$ dibanding dengan perlakuan dosis yang lainnya. Dilihat secara bentuk morfologi, pertumbuhan batang dan daun tanaman indigofera lebih tinggi dibandingkan akar sehingga porsi pemanfaatan hara lebih diprioritaskan pada pertumbuhan di atas tanah, sedangkan tanaman kelor lebih memprioritaskan pertumbuhan di bawah tanah (akar) dibandingkan dengan pertumbuhan daun dan batangnya. Semakin besar nilai berat kering total hijauan daripada berat kering akar maka nilai nisbah berat kering total hijauan dengan berat kering akar yang dihasilkan akan semakin tinggi dan menunjukkan produksi total hijauan. Tanaman dengan proporsi akar yang lebih besar dapat berkompetisi lebih efektif untuk mendapat unsur hara tanah, sedangkan tanaman dengan tajuk yang lebih besar dapat mengumpulkan lebih banyak energi (Allaby, 2004).

Luas daun per pot tanaman indigofera nyata $(\mathrm{P}<0,05)$ lebih tinggi daripada tanaman kelor (1.796,50 $\mathrm{cm}^{2}$ vs 407,63 $\mathrm{cm}^{2}$ ) seperti Tabel 3 , hal ini terjadi dikarenakan secara bentuk morfologi ukuran daun indigofera tumbuh lebih panjang dan lebar dibandingkan dengan daun kelor. Rata-rata panjang dan lebar daun tanaman indigofera yaitu $6,93 \mathrm{~cm}$ dan 2,49 cm (Sirait et al., 2009), sedangkan daun kelor memiliki ukuran daun 1-2 $\mathrm{cm}^{2}$ (Yulianti, 2008). Hasil tertinggi dengan perlakuan dosis pupuk biourin yaitu pada dosis $10.0001 \mathrm{ha}^{-1}$ (D4) sebesar 1.188,38 $\mathrm{cm}^{2}$ berbeda tidak nyata $(\mathrm{P}>0,05)$ dengan perlakuan dosis yang lainnya. 
Tabel 3. Karakteristik Tanaman Indigofera (Indigofera zollingeriana) dan Kelor (Moringa oleifera Lam) pada Dosis Pupuk Biourin Berbeda

\begin{tabular}{|c|c|c|c|c|c|c|c|c|}
\hline \multirow{2}{*}{ Variabel } & \multirow{2}{*}{$\begin{array}{c}\text { Jenis } \\
\operatorname{tanaman}^{1)}\end{array}$} & \multicolumn{5}{|c|}{ Dosis pupuk ${ }^{2}$ ) } & \multirow{2}{*}{ Rataan } & \multirow{2}{*}{ SEM 3$)$} \\
\hline & & Do & D1 & D2 & D3 & D4 & & \\
\hline \multirow{3}{*}{$\begin{array}{l}\text { Nisbah berat kering daun dengan } \\
\text { berat kering batang }\end{array}$} & $\mathrm{TI}$ & 1,84 & 2,17 & 1,99 & 1,77 & 2,09 & $1,97^{\mathrm{X} 4)}$ & 0,23 \\
\hline & TK & 0,31 & 0,45 & 0,29 & 1,02 & 0,36 & $0,49^{Y}$ & \\
\hline & Rataan & $1,07^{\mathrm{A}}$ & $1,31^{\mathrm{A}}$ & $1,14^{\mathrm{A}}$ & $1,40^{\mathrm{A}}$ & $1,23^{\mathrm{A}}$ & & \\
\hline \multirow{3}{*}{$\begin{array}{l}\text { Nisbah berat kering total hijauan } \\
\text { dengan berat kering akar }\end{array}$} & $\mathrm{TI}$ & 3,56 & 3,31 & 5,04 & 2,74 & 2,97 & $3,52^{\mathrm{X}}$ & 0,42 \\
\hline & $\mathrm{TK}$ & 0,34 & 0,29 & 1,15 & 0,36 & 0,68 & $0,5^{6^{Y}}$ & \\
\hline & Rataan & $1,95^{\mathrm{B}}$ & $1,80^{B}$ & $3,10^{\mathrm{A}}$ & $1,55^{\mathrm{B}}$ & $1,82^{B}$ & & \\
\hline \multirow[t]{3}{*}{ Luas daun per pot $\left(\mathrm{cm}^{2}\right)$} & $\mathrm{TI}$ & 1901,28 & 1666,01 & 1754,77 & 1848,23 & 1812,22 & $1796,50^{\mathrm{X}}$ & 111,68 \\
\hline & $\mathrm{TK}$ & 339,65 & 385,95 & 473,08 & 274,93 & 564,53 & $407,63^{Y}$ & \\
\hline & Rataan & $1120,46^{\mathrm{A}}$ & $1025,98^{A}$ & $1113,93^{\mathrm{A}}$ & $1061,58^{\mathrm{A}}$ & $1188,38^{\mathrm{A}}$ & & \\
\hline
\end{tabular}

Keterangan:

1) TI = Tanaman Indigofera (Indigofera zollingeriana), TK = Tanaman Kelor (Moringa oleifera)

2) $\mathrm{Do}=0 \mathrm{l}$ ha-1/ha, D1 $=2.5001$ ha-1, D2 = 5.000 1 ha-1, D3 = 7.500 1 ha-1, D4 = 10.0001 ha- 1

3) SEM = Standard Error of the Treatment Means

4) Nilai dengan huruf kapital yang sama pada kolom yang sama dan huruf kecil yang sama pada baris yang sama menunjukkan berbeda tidak nyata $(\mathrm{P}>0,05)$, sedangkan nilai dengan huruf yang berbeda pada baris dan kolom yang sama menunjukkan berbeda nyata $(\mathrm{P}<0,05)$

Peranan bintil akar juga dapat mempengaruhi luas daun pada tanaman karena bintil akar dapat mengikat nitrogen dari udara sehingga ketersediaan unsur hara nitrogen bagi tanaman semakin meningkat. Hal ini karena unsur hara sangat penting bagi tanaman, semakin besar unsur hara $\mathrm{N}$ yang diberikan maka dapat meningkatkan luas daun pada tanaman. Unsur hara $\mathrm{N}$ berfungsi untuk meningkatkan pertumbuhan vegetatif, sehingga daun tanaman menjadi lebih lebar, berwarna lebih hijau dan lebih berkualitas (Wahyudi, 2010). Nilai luas daun mencerminkan tingkat potensi permukaan yang difungsikan untuk proses fotosintesis. Makin luas permukaan daun, makin tinggi potensi penghasil fotosintat (Sari, 2008).

\section{SIMPULAN}

Berdasarkan hasil penelitian ini dapat disimpulkan bahwa pemberian dosis pupuk biourin mendapatkan hasil yang sama, namun cenderung pada dosis 10.000 $1 \mathrm{ha}^{-1}$ (D4) memberikan pertumbuhan dan hasil tanaman indigofera (Indigofera zollingeriana) dan kelor (Moringa oleifera Lam) yang lebih baik. Terjadi interaksi antara faktor jenis tanaman dengan faktor dosis pupuk biourin pada variabel tinggi tanaman, jumlah cabang, dan berat kering batang.

\section{DAFTAR PUSTAKA}

Adijaya, I.N dan I.M.R. Yasa,. 2007. Pemanfaatan biorin dalam produksi hijauan pakan ternak (rumput raja). Prosiding Seminar Nasional Dukungan Inovasi Teknologi dan Kelembagaan dalam Mewujudkan Agribisnis Industrial Pedesaan. Mataram, 22-23 Juli 2007. Balai Besar Pengkajian dan Pengembangan Teknologi Pertanian. Hal 155- 157.

Adijaya, I N. 2010. Pengaruh Pupuk Kandang dan
Biourin Sapi terhadap Pertumbuhan dan Hasil Jagung (Zea mays L) di Lahan Kering. Program Magister, Program Studi Pertanian Lahan Kering, Program Pascasarjana, Universitas Udayana, Denpasar, Bali.

Aisyah, S., N. Sunarlim, B. Solfan. 2011. Pengaruh urine sapi terfermentasi dengan dosis dan interval pemberian yang berbeda terhadap pertumbuhan tanaman sawi (Brassica juncea L.). Jurnal Agroteknologi. 2(1): 1-5.

Allaby, M. 2004. A Dictionary of Ecology. Oxford University Press Inc, New York.

Blair, G. 1979. Plant Nutrition Copyright The University of New England. Proted and Published by University, New England.

Budiana. 1993. Produksi Tanaman Hijauan Pakan Ternak Tropik, Fakultas Peternakan, Universitas Gajah Mada, Yogyakarta.

Dwijosapoetro, D. 1981. Pengantar Fisiologi Tanaman. PT. Gramedia Pustaka Utama. Jakarta.

Gomez, K. A dan Gomez, A. A. 1995. Prosedur Statistik Untuk Penelitian Edisi Kedua. Jakarta: UI-Pres, hal: 13-16.

Guntoro, S. 2006. Pemanfaatan biourine kambing pada usaha tani bawang merah di lahan kering Kecamatan Grokgak, Kabupaten Buleleng, Bali. Prosiding Seminar Nasional Percepatan Tranformasi Teknologi Pertanian untuk Mendukung Pembangunan Wilayah. Denpasar, 13 Nopember 2006. Balai Besar Pengkajian dan Pengembangan Teknologi Pertanian Bali Hal. 155-157.

Harjadi, M. M. S. S. 1979. Pengantar Agronomi. PT. Gramedia, Jakarta.

Hassen A, NFG Rethman, Van Niekerk, TJ. Tjelele. 2007. Influence of season/year and species on chemical composition and in vitro digestibility of five Indigofera accessions. Anim Feed Sci 
Technol. 136:312-322.

Indriani, Y.H. 2011. Membuat Kompos Secara Kilat. Penebar Swadaya. Jakarta.

Kanisius. 1983. Hijauan Makanan Ternak Potong, Kerja dan Perah. Yogyakarta.

Kerley, S. J., and S. C. Darvis. 1996. Preliminary Studies of the Impact of Excreted $\mathrm{N}$ on Cycling and Uptake of $\mathrm{N}$ in Pasture Systems Using Natural Abundance Stable Isotopic Discrimination. Plant and Soil 178: 287-294.

Kusumawati, N.N.C., N.M. Witariadi, I K.M Budiasa, I G. Suranjaya, N.G.K. Roni. 2017. Pengaruh Jarak Tanam dan Dosis Bio-Urin Terhadap Pertumbuhan dan Hasil Rumput Panicum maximum pada Pemotongan Ketiga. Pastura, Vol 6, No.2. Sumber: https://ojs.unud.ac.id/index. $\mathrm{php} / \mathrm{pastura} /$ article/view/45431.

Mansyur, S. 2008. Pengaruh Inokulasi Rhizobium Terhadap Pembentukan Bintil Akar Kacang Tanah (Arachis hypogaea L.) Ditanam di Hutan Raya Propinsi Bengkulu. Balitbang Mikrobiologi, Puslitbang Biologi - LIPI.

Mansyurdin. 1991. Perkembangan Bintil Akar Pada Tanaman Leguminoceae yang Berasosiasi dengan Rhizobium. Fakultas Matematika dan Ilmu Pengetahuan Alam, Universitas Andalas, Padang.

Mendieta-Araica B, E. Spörndly, N. Reyes-Sánchez, F. Salmerón-Miranda, M. Halling. 2013. Biomass production and chemical composition of Moringa oleifera under different planting densities and levels of nitrogen fertilization. Agroforest. Syst. 87:81-92.

Nuriyasa. I. M, N. N. C. Kusumawati, A. A. A. S. Trisnadewi, E. Puspani, W. Wirawan. 2012. Peningkatan Produksi Rumput Gajah (Pennisetum purpureum) dan Rumput Setaria (Setaria splendida Stapf) Melalui Pemupukan Biourin. Pastura, Vol. 2 No. 2 : 93-96. Sumber: https://ojs.unud.ac.id/index.php/pastura/ article/view/9029/6827.

Sari, F.C.W. 2008. Analisis Pertumbuhan Ubi Jalar (Ipomoea batatas L.) dan Tanaman Nanas (Ananas comosus L.) dalam Sistem Tumpangsari. Skripsi. Fakultas Pertanian Universitas Sebelas Maret. Surakarta
Sirait J, K. Simanihuruk, R. Hutasoit. 2009. The potency of Indigofera sp. as goat feed: production, nutritive value and palatability. In: Proceeding of International Seminar on Forage Based Feed Resources. Bandung, 3-7 Agustus 2009. Taipei (Taiwan): Food and Fertilizer Technology Centre (FFTC) ASPAC, Livestock Research Centre-COA, ROC and IRIAP. p. 4-7.

Steel, R. G. D. dan J. H. Torrie. 1991. Prinsip dan Prosedur Statistika. Diterjemahkan oleh Bambang Sumantri. PT. Gramedia Pustaka Utama. Jakarta.

Sutejo, R. 2002. Pertanian Organik Menuju Pertanian Alternatif dan Berkelanjutan. Penerbit Kanisius. Yogyakarta.

Tarigan, A. L. Abdullah, S .P. Ginting dan I .G. Permana. 2010. Produksi dan komposisi nutrisi serta kecernakan in vitro Indigofera $s p$ pada interval dan tinggi pemotongan berbeda. Jurnal Ilmu Ternak dan Veteriner, 15(3): 188-195.

Tillman, A. D., H. Hartadi, S. Reksohadiprojo, S. Prawirokoesoemo, S. Lebdosoekojo. 1991. Ilmu Makanan Ternak Dasar. Edisi ke-5. Gadjah Mada University Press, Yogyakarta.

Wahyudi. 2010. Petunjuk Praktis Bertanam Sayuran. Agromedia Pustaka. Jakarta.

Widjajanto, D.W., T. Honmura, K. Matsushita, and N. Miyauchi. 2001. Studies on the Release of N From Water Hyacinth Incorporated Into SoilCrop Systems Using 15N-Labeling Techniques. Pak. J. Biol. Sci., 4 (9): 1075-1077.

Widowati, I., S. Efiyati, , S. Wahyuningtyas. 2014. Uji aktivitas antibakteri ekstrak daun kelor (Moringa oleifera Lam.) terhadap bakteri pembusuk ikan segar (Pseedoonas aeruginosa). PELITA, 9(1), 146-157.

Witariadi, N.M., dan N. N. C. Kusumawati. 2020. Dampak pemupukan urea dan biourin terhadap produktivitas rumput Panicum maximum cv. Trichoglume. Majalah Ilmia Peternakan, Vol.23, No.2. Sumber: https://ojs.unud.ac.id/index.php/ mip/article/view/63587/36278.

Yulianti, R. 2008. Pembuatan Minuman Jeli Daun Kelor (Moringa oleifera Lam) sebagai Sumber Vitamin C dan Beta Karoten. IPB, Bogor. 